\title{
\begin{tabular}{lll} 
IFA & Iranian Journal of Finance & $\begin{array}{l}\text { Print ISSN 2676-6337 } \\
\text { Online ISSN 2676-6345 }\end{array}$ \\
\hline
\end{tabular} \\ Modeling the effect of environmental corporate governance rating in the pricing information asymmetry
}

\section{Jaafar Babajani}

Prof., Department of Accounting, Faculty of Accounting and Management, Allameh Tabataba'i University, Tehran, Iran. (Email: babajani@atu.ac.ir)

\section{Mohsen Akbari*}

*Corresponding Author, Ph.D. Candidate, Department of Accounting, Faculty of Accounting and Management, Allameh Tabataba'iUniversity, Tehran, Iran. (Email: mohsenakbari80@gmail.com)

Document Type: Original Article

Received: 2020/09/13

Accepted: 2021/01/12
2021, Vol. 5, No. 1. 91-121

Published: 2021/01/23

\begin{abstract}
Information flow is a key parameter in an economic activity that acts as the main factor in the capital market emergence, stability, and efficiency. The purpose of the current research is to investigate the effect of the environmental points of cooperate governance on the pricing of information asymmetry. In this regard, we have extracted data related to companies accepted in the "Tehran Stock Exchange" from 2009 to 2018, and a panel-data regression model was utilized to test research hypnosis. The results show that information asymmetry and environmental points of cooperate governance have a significant effect on the expected return (cost of capital) on an investment. In addition, the effect of environmental points of cooperate governance on the relationship between the information asymmetry and the cost of capital has been verified. Finally, the results show that environmental points of cooperate governance leads to the differences in the cost of capital in the different levels of information asymmetry.
\end{abstract}

Keywords: Pricing of Information, Environmental Points of Cooperate Governance, Information Asymmetry. 


\section{Introduction}

Information transparency is one of the main conditions of perfect competition without which unequal opportunities will emerge. Information asymmetry deals with the decision of transaction in situations where one party has more information on the product or state of the market compared to the other. In a capital market where investors hold different information on securities or market mechanisms, their recognition of a state will be different. In other words, there is information asymmetry. Investors with low information may withdraw securities exchange or stock market assuming that clearly there exists information asymmetry. Firm governance (cooperate governance) system is one of the main factors to improve economic efficiency that includes a set of relationships between company management, board, shareholders, and other interest groups. The firm governance system provides a structure by which firms' goals will be set and the means of achieving goals and monitoring performance be determined. This system creates the necessary incentive to achieve the firm's goals and provide the basis of effective supervision. Therefore, the companies utilize the resources more effectively. In the stock exchange, information asymmetry is one of the main effective factors for adverse decisions and those non-related to the subject. Utilizing the information of issuers of securities, or in other words, making the right decisions in the stock exchange market will be possible if the complete and crucial information provided in a timely manner is relevant and intelligible. If the required information is distributed asymmetrically, or in other words, the information transferred unequally between individuals, we can expect different results to a single topic. In a world with information symmetry, it is assumed that managers and the market hold the same information about the company or none. Therefore, managers and the market bear uncertainty about the company. In a world with information asymmetry, however, managers have more information on the company compared to the others due to having private and confidential information about companies. In other words, they have access to certain information about the company prior to the market. Relevant company information is transferred to the market over time through informationdisclosing events (Drobetz et al., 2016).

Information asymmetry in a company equals uncertainty about the firm since it is likely that managers and the market have equal knowledge about the impact of market variables on the company value. Market response to earnings announcements can be the first measure of information asymmetry in a company through information disclosure. Information asymmetry can be 
determined depending on the information environment, the multiplicity of public announcements, and the number of company transactions and also affected by the behavior of managers or the market. For example, it is possible for the market to have more knowledge about the actual state of the company at the time of public announcement and information asymmetry may be reduced. It is assumed that the more information is distributed in the market unequally through unofficial channels, the greater the scope of information asymmetry and bid-ask spread will be (Khodami Pour and Ghadiri, 2010).

Information flow affects the market participants in the market environment. Changes in the market environment result in situations so that market participants have different shares of this information flow. Empirically, individuals have different information that leads to an impact on their behavior in many cases representing the information asymmetry between the parties of a transaction (Lowry, 2005). This information asymmetry is due to different information flows between market participants. Limitation of information framework in theoretical models and the criteria utilized in experimental works has led to more ambiguities in the interpretation of existing literature on the effect of information risk. It is most common in researches, however, to consider accounting information as the most crucial source of the information environment which is defined as a system for the transfer of information and reduction of uncertainty. That is, in other words, the information approach to accounting. Accounting information gives investors the ability to evaluate the company and the inherent risks involved. High-quality accounting information is useful for investors because of its effect on share prices and turnover. Factors that can result in complications in the accounting information environment include heterogeneity in investors' interpretations, and information inequalities emerged as a result of the irregularity in information gathering and processing due to the different methods and skills utilized (Dou et al., 2015).

Corporate governance, according to Owen et al (2010), can be defined as the set of control mechanisms that protect the suppliers of capital to a company, particularly suppliers of equity capital, the shareholders, who have only residual protection after all other claims have been satisfied. In other words, mechanisms that can improve the quality of raw information and, consequently, financial reports provide an incentive for managers to deploy capital efficiently.

The accounting information environment is complicated due to two reasons: firstly, information is the output of accounting and, secondly, information is something more than just an effect on an individual decision. In 
fact, individuals are not unanimous in response to similar information that can result in more complications in the information environment (Scott, 2009). Therefore, researchers have added recognition of this information environment in their agenda. Investors rate the risk that they give to accounting information in accordance with their assessment of the information environment's features. The lower uncertainty and higher reliability of the accounting environment they encounter, the lower risk of information they apply. As the risks decline, thus, they require less return and the firm incurs fewer capital costs. Where a turbulent information environment exists, investors will search for mechanisms to assess information risk.

According to the theories, the level of exploitation of private information by informed traders, as the quality of disclosure increases, will decline for a certain level of information asymmetry since the quality of disclosure leads to faster reflection of news on prices. In other words, the quality of disclosure reduces the need for market brokers and, also the risk of information asymmetry for retail investors since informed investors lead to a higher reflection of information on prices (Easley and O'Hara, 2007). The companies have exclusive ownership of their information in such a way that the transfer of their added value to investors will be prevented. Any attempt to acquire information through other channels available in the capital market will lead to the imposition of unrealistic information risk on the investor and part of the expected return is limited in the form of costs of acquiring information. According to the literature on information economics, the quality of disclosure leads to the transfer of value from the company to shareholders, and the cost of capital will decline due to information competition (Dutta and Nezlobin, 2018).

Information risk is due to two factors including ambiguity (quality of information) and information distribution (information asymmetry). The quality of accounting information is mainly derived from indices that are based on accounting figures reflected in the content of financial statements and explanatory notes. Information distribution, however, is influenced by this perception in which information is considered to be a commodity. In other words, accounting information is a commodity. This is a claim made in information economics theory. In the current study, the reflection of each of these two features, related to the accounting information environment, in prices is examined. We also examine another claim in the current study. The information environment is derived from the market state. In other words, corporate governance affects the considerations of the pricing of information asymmetry. Therefore, the study attempted to address the following research questions: 
1. What are the main variables that affect the pricing of information asymmetry?

2. Is the point of cooperate governance affect the pricing of information?

3. Is it possible to establish a relationship between the features of the information environment and the company's cost of capital considering the corporate governance point?

The structure of the present study is as follows. First, we present the theoretical bases and literature review. Next, we have provided hypotheses, models, and methods utilized in the current research. Finally, we finish our research with a conclusion and suggestions.

\section{Research background}

\section{Theoretical Basis}

Investors' responses in the capital market are due to information being available in these markets. Each Investor's response is based on the level of information acquired. Therefore, the information may not be distributed to all investors equally and simultaneously. There is clearly an information asymmetry between the two parties at issue (Lauri, 2003). Different information flow between the investors may lead to the occurrence of information asymmetry. With the occurrence of information asymmetry, the possibility of trading in the capital market will decline. In other words, lesser quality of information will result in a gap between informed and uninformed investors. This information gap will, in turn, result in the intensification of the company's lack of access to external financing and increase the capital cost.

According to studies carried out, corporate governance indices can effectively prevent unfavorable management decisions, investment risk, and consequently stock price volatility (Minnick \& Noga, 2010) by regularization of investment (Wang and $\mathrm{Ki}, 2007$ ), avoiding management misuse, and promoting the level of information provided (Karmono and Vefis, 2005).

In situations where information asymmetry occurs, external financing will be information-sensitive. In such situations, internal financing will be preferred over external financing. In case that information asymmetry occurs, if there are no sufficient sources of cash to finance projects with a positive net present value (NPV), the managers may avoid investing in profitable projects. In this case, cash holds more value for the company (Drobetz et al., 2016). To reduce the costs resulted from information asymmetry, financing policy must comply 
with a hierarchical procedure. For example, companies finance their investment projects using retained earnings, then debts that bear little risks for the company and next high-risk debts, and If necessary, through the issuance of share. As a result, since the management of local resources prefers financing over external resources, they tend to retain the cash.

In companies where there is high free cash flow, it is likely that, due to the agency problem, managers will engage in unprofitable activities by misusing mentioned funds and are not eager to reduce the excess cash e.g., dividend (Drobetz et al., 2017). According to the agency theory, on the other hand, such opportunistic behavior will result in unfavorable results for the company and owners (Benkenz, 2006). Meanwhile, the corporate governance mechanism on quality is one of the main factors to reduce the cost of information asymmetry and agency problems (Derano and Kim, 2010). In case the companies were able to finance with ease by being active in perfect markets, measures that are taken to promote the quality of cooperate governance and reduce the agency costs will be considered as extra. However, companies are not active in the perfect markets and the available evidence also confirms the existence of deficiency in the capital market.

Based on the investor recognition hypothesis (Merton, 1987), these investors are likely to invest in or trade with companies that appeared legitimate or are judged to be legitimate. In case the quality of cooperate governance increases, the company's visibility will grow and the costs of company-specific public information processing decline. As the quality of cooperate governance improves, the extent of trading by uninformed investors will grow (Brown and Hillegeist, 2007). In addition, according to Diamond (1985), issuing public information will homogenize traders' beliefs and reduces the intensity of speculative situations by informed traders. Fishman and Hagerty (1987) provided a similar discussion. While the high number of uninformed trading will result in the reduction of trading based on private information, past researches have posited that the more uninformed tradings are, the more informed trading will be, considering that all other factors are constant.

Improving the quality of cooperate governance will reduce the investors' incentives to seek out private information by reducing the profits, expected by acquiring private information (Diamond, 1985; Verrecchia, 2001). Diamond (1985) found that investors' incentives to acquire private information will decrease when companies disclose information publicly. Companies with highquality corporate governance are most likely to disclose important information 
to the public and thus providing more forward-looking information. As a result, it is expected that the high quality of corporate governance will reduce the incentives to seek out private information.

Previous studies showed that the quality of corporate governance has a negative relationship with the frequency of private information events. Gelb and Zarowin (2002) and Lundholm and Myers (2002) find that current stock returns reflect more information about future earnings when disclosure quality is higher. These results imply that by "bringing the future forward," more informative disclosures reduce the total set of information about future earnings that can be privately discovered about a firm (Brown and Hillegiest, 2011). Since there is less information available to be discovered, in addition to the reduced search incentives discussed above, we expect that the frequency of private information events will be declining in disclosure quality.

The available evidence shows that capital markets are not efficient. Therefore, the intervention of regulatory bodies is required to promote corporate governance and increase the accountability of managers to shareholders and other beneficiaries (Solomon, 2010). Also, since many capital markets are not efficient, the stock price of companies is a function of the improvement rate of mechanisms that are expected to make a solution for information asymmetry and agency problems. The results of some financial researches have shown that the improvement of corporate governance mechanisms will increase information quality and consequently the stock price (Gopta and Sharma, 2018). It must be noted that the quality of information can result in an increase in the quality of financial reporting. Information is not just a basis of decision making but it is a valuable asset that strategically generates competitive advantage (Chen and Liang, 2017). Corporate governance mechanisms are those structures that can affect the quality of information and consequently the reporting of this effective information. Corporate governance mechanisms can result in an increase in information efficiency by improving the environment in which information is formed (Gopta and Sharma, 2018).

There is a belief in companies that legitimate corporate governance will facilitate the management and control of business unit effectiveness; therefore, an optimum efficiency can be provided for all the beneficiaries in the company. Lack of sufficient and reliable information whose distribution is done unequally into the markets will result in poor decisions by the participants in these markets and the non-optimal allocation of their financial resources. This phenomenon is known as information asymmetry in the accounting literature. Information asymmetry has different unfavorable consequences that include: 
decreased market efficiency, increased transaction costs, market failure, low liquidity, and in general, reduced profits resulted from trading in capital markets (Khodamipour and Ghadiri, 2010). The occurrence of inequality can be seen between two groups of participants in these markets.

There are two types of information asymmetry that occurs: in one hand, there is information asymmetry between management as the holders of the company's final information, and the other one between external individuals who need the information to evaluate the company's profitability, how to perform management stewardship function and evaluate his/her performance, in the other hand. These types will occur due to a lack of sufficient information on the management performance for investors and the inability of investors to observe the results of management performance. Since stock prices in an efficient market are estimated based on the available information, insufficient information will be reflected in the estimation of wrong prices and bring out pricing bias or non-realistic pricing in the market (Jones, 2005).

The existence of sufficient information and its rapid reflection in the price of securities promptly is closely related to market efficiency. The stock exchange is bound to create an efficient market in which securities can be traded at a fair price at any time. An increase in the level of market efficiency will result in the improvement of the price discovery mechanism, thus optimizing the pricing and increasing the possibility of rationally predicting price trends. When the prices determined in a stock exchange reflect all the relevant information available, these prices can be considered along with the appropriate criteria for optimal allocation of scarce capital. In turn, improved transparency will result in increased competition between market participants, reinforce available relations between market participants and investors, and facilitate control affairs and operation of the law (Ferancis et al., 2005). Baghi Foroughi and Ahmadi (2010), by studying the quality of accounting information and shareholder composition in their paper, concluded that the companies with a shareholder composition consisted of institutional investors will have accruals with quality better than companies with a shareholder composition consisted of individual investors.

Based on the prediction made in information economics theory, the quality of accounting information will reduce the information asymmetry between the managers and investors, thus the cost of capital will decline. The efficient models of capital market predict that company disclosure can anticipate the acquisition of private information or act as an alternative to information held by investors, by which the investors' incentive or ability to 
acquire private information will decline. As a result, uninformed traders are most likely to trade with companies that have a great volume of transactions and high liquidity. This output occurs due to the fact that more transparency will reinforce the stock market liquidity and reduce transaction costs for the company's stocks (Diamond and Verrecchia, 1991). Atiase (1987) argues that the company's information varies positively with the firm size. Therefore, companies with lower levels of information are expected to create more opportunities for informed trading against the market maker, thus increasing the cost of adverse selection. There are occasions where theory predicts a positive relation between disclosure and information asymmetry. These situations occur immediately surrounding information events (Van Buskirk, 2012).

Based on the theories, the exploitation rate of private information by informed traders at a certain level of information asymmetry will be minimum in situations where we have a lesser market failure (e.g., Dou et al., 2015; Chung, et al., 2014). The reason is that the quality of information, eventually, will cause private information to be incorporated into prices more quickly (in other words, prices become more informative about fundamental value). According to the above-mentioned researches, the quality of accounting information eventually will be reflected in the prices. This phenomenon has two potential considerations for the pricing of information asymmetry. Firstly, the quality of accounting information reduces the need for market makers to price protect because it lowers the extent to which information asymmetry is exploited (Kili, 1985). Secondly, it reduces the risk of information asymmetry to uninformed investors because the collective transactions by informed investors lead to greater information being reflected in the equilibrium price (Easley and O'Hara, 2004). If more traders are informed, then private information prices will be reflected more quickly and this makes the information asymmetry less risky for uninformed investors. Also, it reduces the quality of information asymmetry that can be exploited and hence, earnings that can be obtained by informed investors.

We have a horizontal demand curve in the perfect competition of stock exchange; hence the demand has no effect on the price. For defective competitive stock markets, however, each informed investor has a selfsustaining belief that he faces a downwardly sloping demand curve or an upwardly price curve for the company shares (Lambert and Verrecchia, 2010), and each investor detect the effect on the price. Therefore, the transactions of more informed investors will affect the price. When investors have different levels of knowledge with different price curves, it is likely that information 
asymmetry (as a reflection of different levels of knowledge) appears at the prices. The result will be the change in the capital price.

Lambert et al., (2012) showed that when the capital market is characterized by perfect competition and investors act as price-takers (as is the case in the Capital Asset Pricing Model (CAPM) and most noisy RE models), information asymmetry cab affects the cost of capital even after controlling for investors average precision. In this setting, cooperate governance can reduce information asymmetry between investors and also reduce the cost of capital. But this effect on the cost of capital occurs solely because increasing the two above factors, simultaneously, increase the average precision of investors, not because it reduces information asymmetry, per se.

\section{Empirical Background}

Sharder (2020) has studied the role of asymmetric information on changing the capital cost and concluded that various factors e.g., the quality of disclosure, corporate governance, and information accuracy lead to a change in the relationship between the quality of accounting information and the cost of capital.

Ben Kor et al., (2020) found that there is a significant positive relationship between the information asymmetry and costs stickiness, which also affects the relationship between information asymmetry on conditional conservatism.

Johnson \& So (2019) examined asymmetric trading costs before earnings announcements. Their sample consists of 754,215 quarterly earnings announcements from 1996 to 2005. The results showed that the cost of trading on negative news, relative to positive news, increases before earnings announcements. Their evidence suggests this asymmetry is due to financial intermediaries reducing their exposure to announcement risks.

Cai et al., (2019) came to the conclusion that firms facing greater asymmetric information tend to use less intensive board monitoring. They showed that high information-asymmetry firms that have to substantially increase board monitoring intensity after the Sarbanes-Oxley Act to prevent managers from taking opportunistic measures. They also examined the relationships between asymmetric information and the three governance mechanisms including intensity of board monitoring, market discipline, and CEO pay-for-performance sensitivity. They concluded that firms facing greater asymmetric information tend to use less intensive board monitoring but rely more on market discipline and higher performance of CEO. 
Nagar et al., (2018) by examining the interactive effects of environmental uncertainty, information asymmetry, and disclosure come to this conclusion that uncertainty about firm value drives actions such as an investor's decision to collect private information. In this regard, environmental uncertainty will lead to a change in the purchase and stock prices, thus stock value declines.

Li et al., (2017) by examining the effect of ownership structure and interorganizational relations concluded that controlling shareholders can acquire information, affect the time, and the method by which information is presented into the capital market. Thus, an increase in information asymmetry will lead to a change in the process of dividing company profit that is decline relative to prior years and most of the changes are due to the company's control structure.

Chen et al., (2016) in their research on inter-organizational information asymmetry and information environment concluded that firms facing greater asymmetric information will provide weaker and limited management forecasts that are highly deviated from reality. Therefore, the likelihood of revaluation of information increases in the future. They also posited that the existence of legitimate cooperate governance will result in an increase in the quality and quantity information disclosed by the company, thus information asymmetry declines.

To examine the effect of information asymmetry on capital cost, Lambert et al., (2012) incorporated two variables e.g., perfect competition and information precision (quality). Theirs analyze model showed that when the capital market is characterized by perfect competition and investors act as price-takers (as is the case in the capital asset pricing model (CAPM) and most noisy RE models), information asymmetry can affect the cost of capital even after controlling for investors average precision. In this setting, an increase in the quality of information available to the public can reduce the information asymmetry between investors, thus reducing the cost of capital.

Cormier et al., (2010) investigated the effect of governance on information asymmetry between managers and investors and concluded that some formal monitoring attributes (board and audit committee size), as well as the extent of voluntary governance disclosure, reduce information asymmetry. The number of audit committee meetings can lead to a reduction in asymmetry, while the opposite is observed for board meetings. Other results showed that an independent board, strategic management disclosure, and directors' disclosure have an impact on total disclosure. However, these two board independence variables neither affect stock price volatility nor Tobin's Q (as the information asymmetry variables). 
By focusing on European companies, Bauwhede and Willekens (2008) showed that companies disclose corporate governance information in order to reduce information asymmetry and agency costs stemming from the separation between ownership and control and to improve investor confidence in the reported accounting information.

Ebrahimi et al., (1399) in their research reviewed the role of competitiveness in the pricing of account information quality and asymmetry. In this research, three characteristics of the accounting information environment e.g., asymmetry, quality, and competitiveness, as well as their effects on the cost of capital were studied. The results of testing questions show that the degree of competitiveness affects the pricing of information asymmetry and quality and competitiveness affect the reflection rate of two variables asymmetry and quality on the prices.

Vakili and Saeidi (1398) investigated the relationship between the restatement of information and information asymmetry amongst the companies listed in the Tehran Stock Exchange. The results show a significant and positive relationship between information asymmetry before the general annual meeting and prior period adjustment as well as a negative significant relationship with the size of the companies. While, the significant relationship between information asymmetry before the meeting and the other variables including return on the assets, leverage, and operating cash flow is not approved.

Joudi and Mansourfar (2019) in their research "Information Asymmetry, Internal and External Dimensions of Corporate Governance Quality: Improving or Worsening Audit Quality?" showed that there is a negative relationship between corporate governance and audit quality in the companies with higher information asymmetry. The existence of corporate governance does not improve audit quality, however, in companies with low information asymmetry, cooperate governance will result in the improvement of audit quality. They also concluded that the existence of information asymmetry has greater impacts on audit quality than the corporate governance quality and information asymmetry distorts the positive relationship between corporate governance and audit quality.

Joudi and Mansourfar (2019) in another research "Internal and External Corporate Governance Quality, Information Asymmetry, and Cash Holdings: Increase or Decrease in the Firm Value?" showed that the higher (lower) quality of corporate governance in the presence of information asymmetry will have a significant and positive (negative) effect on the relationship between 
cash holdings and firm values. Not only, these results were confirmed by considering the separated internal and external dimensions of corporate governance but also by integrating both dimensions of cooperate governance quality.

Consequently, in the conditions of information asymmetry, the presence of strong corporate governance mechanisms impedes the emergence of agency costs, and thus the value of the company increases.

Rashidi Baghi et al. (2019), in their study, investigated the modeling of the interactive effect of quality disclosure on the pricing of information asymmetry. The results of their study show that the pricing of information asymmetry is a function of the disclosure quality criteria, and the capital cost stemmed from information asymmetry fluctuates and changes at the different levels of disclosure quality. In other words, information asymmetry significantly impacts the expected return; however, the capital cost imposed on the company also suffers from fluctuation and alteration when the level of disclosure quality shifts.

In their course of study, Baghani et al. (2018) delved into the relationships of corporate governance and information asymmetry to the stock return of companies accepted in the Tehran Stock Exchange. The findings of the research denote that there is a negative significant relationship between corporate governance and information asymmetry, a significant relationship between the indices of corporate governance and information asymmetry, and a negative significant relationship between information asymmetry and stock return.

In a study, Kamyabi et al. (2018) examined the effect of the mechanisms of the corporate governance system on the expenses of stock trades. Their research findings displayed that dominant owners reinforce information asymmetry among the minority stockholders and unaware investors by accessing the confidential and internal information of the company, and thus the costs of stock trades rise. Moreover, the ownership of managers, due to personal motives, makes the investors slowly perceive and process the information and impose the costs of stock trades on investors. The other results of the study showed that owing to the supervisory role of the independent members of the board of directors in the managers' activities, the information quality enhances, and the cost of stock trades shrinks.

In a study, Samadi Lorghani (2017) investigated the effect of corporate governance point on the value of information feedback and accounting performance. The results of this study revealed that a single-unit change in the 
corporate governance point led the unit of the accounting performance index to increase by $19 \%, 11 \%$ of which had a direct effect, and $8 \%$ had an indirect effect. This issue indicated the effect of information quality on the relationship between corporate governance and performance.

Pourzamani and Naseri (2015), in their study, probed the mutual effect of disclosure and conservation on the capital cost and concluded that there was a negative significant relationship between disclosure and capital cost, and capital cost decreased as conservation increased. They showed that, according to the information asymmetry theory, disclosure quality resulted in a significant relationship between conservation and capital cost.

Yadolahzadeh Tabari and Imamgolipour (2014) explored the effect of corporate governance and auditing quality on the balanced average of companies' capital cost and conducted a comparative analytical study based on auditor size, firm size, and income smoothing and not-smoothing firms. The results exhibited that there were no significant relationships of corporate governance mechanisms and auditing quality to the capital cost. Besides, in big companies, the large size of the board of directors, along with the presence of control stockholders, could reduce the capital cost of the company.

Rahimian et al. (2009) claimed that there were no significant relationships among internal auditing, the ratio of the non-executive managers of the board of directors, and the indicators of information asymmetry; however, there was a negative significant relationship between the ownership percentage of institutional investors and information asymmetry.

Concerning the theoretical foundations and research background and given the study purpose, which is investigating the effect of corporate governance point on the pricing of information asymmetry, the following research hypotheses are developed:

Hypothesis 1: The environmental point of corporate governance affects the relationship between information asymmetry and return.

Hypothesis 2: The environmental point of corporate governance gives rise to a difference between companies with high information asymmetry and those with low information asymmetry in their capital costs.

\section{Research models and variables}

\section{Research Models}

This study seeks to investigate the pricing of information asymmetry based on the environmental point of corporate governance. To this end, it employs the 
below models to examine the research hypotheses.

Hypothesis 1

$\mathrm{R}_{\mathrm{i}, \mathrm{t}+\mathrm{l}}=\alpha_{0}+\alpha_{1} \mathrm{ROA}+\alpha_{2}$ Size $_{\mathrm{i}, \mathrm{t}}+\alpha_{3} \mathrm{LEV}_{\mathrm{i}, \mathrm{t}}+\lambda_{1} \mathrm{IA}_{\mathrm{i}, \mathrm{t}}+\lambda_{2} \mathrm{GOVERNANCE}_{\mathrm{i}, \mathrm{t}}+\lambda_{3}$

$\mathrm{IA}_{\mathrm{i}, \mathrm{t}} \times \mathrm{GOVERNANCE}_{\mathrm{i}, \mathrm{t}}+\varepsilon_{\mathrm{i}, \mathrm{t}+1}$

Where

$\mathrm{R}_{\mathrm{t}+1}$ is the expected return of the stock $i$ in 12 months based on the adjusted 5factor model of Fama and French.

ROA is the return of assets. It is one of the controlling factors and is equivalent to the ratio of the net profit to the total assets of the period initial.

Size is a controlling factor and equals the natural logarithm of the capital market value at the end of year $t$.

LEV is one of the controlling factors and is equivalent to the ratio of the firm's debts in year $t$ to the total assets at the end of financial year $t$.

IA is the information asymmetry variable of stock $i$ for the year t. This variable is computed by the several ways mentioned in the following:

a) Bid and ask fluctuation, which equals the standard deviation of the stock price before and after the earnings announcement time (Venkatesh \& Chiang, 1986; Ghaemi \& Vatanparast, 2005).

b) Effective spread is calculated as below:

$$
\begin{array}{ll}
\text { Percentage effective } & 2 \mathrm{D}_{\mathrm{it}}\left(\text { Price }_{\mathrm{it}} \mathrm{Mid}_{\mathrm{it}}\right) \\
\cline { 2 - 2 } \text { spread }= & \operatorname{Mid}_{\mathrm{it}} 100
\end{array}
$$

Where Price ${ }_{i t}$ is the trade price of stock $i, \mathrm{Mid}_{\mathrm{it}}$ is the median of the bid and ask prices before time $t$, and $\mathrm{D}_{\mathrm{it}}$ is a twofold variable. It equals 1 if it is a bid order and -1 if it is an ask order (Bhattacharya, Desai, \& Kumar, 2011).

Governance is the governance environmental point index of a company $i$ and is estimated and scored by the below pattern and based on the structural equation modeling.

$$
\begin{aligned}
& \text { PRICE = F(Constant + INDEPENDENCEi,t + DUALi,t +INST OWNi,t + } \\
& \text { COMPETITIONi,t +BOARD MEMBERi,t + COMPENSATIONi,t +BIG } \\
& \text { OWNi,t + DEBT RATIOi,t +MARKET VALUEi,t })
\end{aligned}
$$


In the above regressions, the coefficient of concern for testing the role of the environmental point of corporate governance in the pricing of information asymmetry is ${ }_{3} \lambda$, which is the coefficient of the relationship between the environmental point of corporate governance and information asymmetry. According to the questions and the conceptual model of the study problem, the pricing of information asymmetry decreases when the environmental point of corporate governance increases; thus, we expect negative coefficients. Indeed, the negative coefficient in this mutual relationship indicates that the environmental point of corporate governance is related to the pricing level of information asymmetry. The significant coefficients of these variables are tested at the significance level of $95 \%$.

The test of the third and fifth sub-questions of the research is, in fact, the test of return and information environment characteristics. The below processes are advanced for the testing of these two questions:

1. Companies fall into five quantiles based on the index of the corporate governance level. It is expected that the quantile with minimum (maximum) index value has deficient (relatively full) efficiency.

2. Then, the companies are categorized into five quantiles based on the index of information asymmetry degree (for the second question). Although we can hardly observe the information asymmetry level directly, we expect that the quantile with the minimum (maximum) index value to have the minimum (maximum) information asymmetry. It is predicted that, in the quantile that is closer to the lower corporate governance, the companies with relatively high information asymmetry have lower efficiency compared to the companies with low information asymmetry. It is also predicted that, in the quantile that is closer to full corporate asymmetry, the companies with a relatively high degree of information asymmetry have approximately return equal to the companies with a low degree of information asymmetry. The below table shows the quantiles.

Table1. Quantilization of companies based on Corporate Governance Point

\begin{tabular}{|c|c|c|c|c|c|c|}
\hline \multirow{3}{*}{$\begin{array}{c}\text { according to } \\
\text { Information } \\
\text { Asymmetry } \\
\text { Index }\end{array}$} & $\begin{array}{c}\text { Full }\left(\mathrm{Q}_{10}\right) \\
\text { Asymmetry }\left(\mathrm{Q}_{01}\right)\end{array}$ & $\mathrm{Q}_{20}$ & $\mathrm{Q}_{30}$ & $\mathrm{Q}_{40}$ & Deficient $\left(\mathrm{Q}_{50}\right)$ \\
\cline { 2 - 6 } & $\mathrm{Q}_{02}$ & $\mathrm{Q}_{21}$ & $\mathrm{Q}_{31}$ & $\mathrm{Q}_{41}$ & $\mathrm{Q}_{51}$ \\
\cline { 2 - 7 } & $\mathrm{Q}_{03}$ & $\mathrm{Q}_{13}$ & $\mathrm{Q}_{22}$ & $\mathrm{Q}_{32}$ & $\mathrm{Q}_{42}$ & $\mathrm{Q}_{52}$ \\
\cline { 2 - 7 } & $\mathrm{Q}_{04}$ & $\mathrm{Q}_{14}$ & $\mathrm{Q}_{24}$ & $\mathrm{Q}_{33}$ & $\mathrm{Q}_{43}$ & $\mathrm{Q}_{44}$ \\
\cline { 2 - 7 } & $\begin{array}{c}\text { High Information } \\
\text { Asymmetry }\left(\mathrm{Q}_{05}\right)\end{array}$ & $\mathrm{Q}_{15}$ & $\mathrm{Q}_{25}$ & $\mathrm{Q}_{35}$ & $\mathrm{Q}_{45}$ & $\mathrm{Q}_{54}$ \\
\hline
\end{tabular}


3. After the companies are arranged into $25(5 \times 5)$ portfolios per year, the future return of the envelope portfolio, which adopts a bid condition in companies with the highest level of information asymmetry and an ask condition in companies with the lowest level of information asymmetry, is estimated for every quantile. The adjusted five-factor model of Fama and French (1993) is used for the calculation of the capital cost. Put differently, the time-series regression of the return of the envelope portfolio of the information asymmetry is estimated according to five factors of the market, size, momentum, and the ratio of the book value to the market:

$$
R_{H t}=\mathrm{a}_{\mathrm{H}}+\beta_{1}(\mathrm{RM}-\mathrm{RF})+\beta_{2} \mathrm{SMB}+\beta_{3} \mathrm{HML}+\beta_{4} \mathrm{RMW}+\beta_{5} \mathrm{CMA}+\varepsilon_{t}
$$

$\mathrm{R}_{\mathrm{H}}$ is the return that is related to the envelope portfolio of the information asymmetry.

4. The considered variable here is the fixed component of $a_{H}$. If $a_{H}$ is significantly larger than 0 , the companies with high information asymmetry will earn an adjusted capital cost with higher risk as compared with the companies with low information asymmetry.

5. In this stage, the significance of the factor loadings of the considered variable $\left(\mathrm{a}_{\mathrm{H}}\right)$ is tested by the $t$ static at $1 \%, 5 \%$, and $10 \%$ levels.

\section{Statistical population and method of company selection}

The understudy statistical population of this research is all companies accepted in Tehran Stock Exchange between the years 2009 and 2018. For the selection of the samples from all present companies, the ones that did not enjoy the below conditions were removed, and, finally, the remaining companies were selected for testing.

1. For the homogenization of the statistical population in the understudy years, the companies should have been accepted in Tehran Stock Exchange before 2009.

2. Concerning the comparability enhancement, the financial period of the companies should eventuate in late March.

3. The statistical population does not include the financial intermediate, investment, leasing, banking, and insurance companies since the nature of the assets of these companies are different.

4. The companies should not have changed their practice or financial period in the time of this research.

5. The data of the considered companies should be available.

Lastly, the understudy companies of the research included 120 companies accepted in Tehran Stock Exchange. 


\section{Research findings}

\section{1- Descriptive statistics}

To present a general scheme of the main characteristics of the estimated variables, the below table illustrates some descriptive statistics of these variables, including mean, median, standard deviation, minimum, and maximum.

Table 2. Descriptive statistics of research variables

\begin{tabular}{|c|c|c|c|c|c|}
\hline Variables & Mean & Median & SD & Maximum & Minimum \\
\hline \multicolumn{7}{|c|}{ Information Asymmetry Indices } \\
\hline Bid and Ask spread & -0.0154 & -0.0132 & 0.0184 & 0.0000 & -0.3002 \\
\hline Effective spread & 0.0579 & 0.0460 & 0.0865 & 0.2684 & 0.0003 \\
\hline Variables Affecting the Auditing Information Environment \\
\hline Financial Leverage & 0.6614 & 0.6679 & 0.2179 & 1.8244 & 0.0405 \\
\hline Return of Assets & 0.1326 & 0.0537 & 0.2226 & 1.2046 & -0.4323 \\
\hline Company Size & 5.8773 & 5.8214 & 0.6161 & 8.5200 & 4.2464 \\
\hline Corporate Governance & 0.0824 & 0.0809 & 0.0539 & 0.2930 & 0.0002 \\
\hline Earning Quality & 0.2638 & 0.1010 & 0.5859 & 1.9207 & 0.0000 \\
\hline \multicolumn{7}{|c|}{ Excess Return Index } \\
\hline Capital Cost & 0.0999 & 0.0531 & 0.2827 & 0.8972 & -0.7952 \\
\hline
\end{tabular}

By examining the quantitative results of the descriptive statistics of the research variables and concerning the above table, we consider the -0.0154 and 0.0579 values as the mean of information asymmetry (bid and ask spread and effective spread). In other words, the bid price among the understudy companies is lower than the asking price since the obtained mean is significantly far from the possible maximum offer price. The mean of company size equals 5.8773, and corporate governance means, 0.0824 , indicates the limited deviation from the standard model of corporate governance among the understudy companies. The financial leverage mean equals 0.6614 . That is, the companies more embark on debt financing. The 0.1326 mean shows the return of assets, where 13.26 rials of return are earned for every 100 rials of investment in assets.

\section{2- Reliability test of research variables}

The presence of unstable variables in the model causes the Student and Fisher tests do not have the necessary validity and the critical quantities provided by these distributions are not the correct values for performing statistical tests.

According to Table 3, the results of the reliability test of variables show that the error level of all variables is less than $5 \%$ and the research variables are 
stable; as a result, the use of variables in estimating research models does not lead to false regression.

Table 3. Results of the reliability test of variables

\begin{tabular}{|c|c|c|c|c|c|c|c|c|}
\hline \multirow{2}{*}{ Variables } & \multicolumn{2}{|c|}{$\begin{array}{c}\text { Fisher, Phillips } \\
\text { Pro }\end{array}$} & \multicolumn{2}{|c|}{$\begin{array}{c}\text { Fisher Dickey } \\
\text { Fuller }\end{array}$} & \multicolumn{2}{|c|}{$\begin{array}{c}\text { Am pesran and } \\
\text { Shin }\end{array}$} & \multicolumn{2}{|c|}{$\begin{array}{c}\text { Levin, Lane and } \\
\text { Ch }\end{array}$} \\
\cline { 2 - 10 } & p.v & Statistics & p.v & $\begin{array}{c}\text { Statisti } \\
\text { cs }\end{array}$ & p.v & Statistics & p.v & Statistics \\
\hline $\begin{array}{c}\text { Bid and Ask } \\
\text { Spread }\end{array}$ & 0.00 & 254 & 0.00 & 124 & 0.00 & -35.8 & 0.00 & -19.5 \\
\hline $\begin{array}{c}\text { Effective } \\
\text { distribution }\end{array}$ & 0.00 & 154 & 0.00 & 310.4 & 0.00 & -45.9 & 0.00 & -7.81 \\
\hline $\begin{array}{c}\text { Financial } \\
\text { Leverage }\end{array}$ & 0.00 & 153 & 0.00 & 123.5 & 0.00 & -66.9 & 0.00 & -5.3 \\
\hline Return on assets & 0.00 & 159 & 0.00 & 124 & 0.00 & -71.7 & 0.00 & -22.6 \\
\hline $\begin{array}{c}\text { size of the } \\
\text { company }\end{array}$ & 0.00 & 225 & 0.00 & 163 & 0.00 & -120.5 & 0.00 & -50.5 \\
\hline $\begin{array}{c}\text { corporate } \\
\text { governance }\end{array}$ & 0.00 & 246 & 0.00 & 98 & 0.00 & -95.1 & 0.00 & .36 .12 \\
\hline $\begin{array}{c}\text { Quality of } \\
\text { information }\end{array}$ & 0.00 & 421 & 0.00 & 104.0 & 0.00 & -25.5 & 0.00 & -85.7 \\
\hline \begin{tabular}{c} 
Cost of Capital \\
\hline
\end{tabular} & 0.00 & 275.1 & 0.00 & 120.5 & 0.00 & -33.4 & 0.00 & -6.55 \\
\hline
\end{tabular}

\section{3- Model estimation by combined data}

Chow test was used to choose between panel data methods and integrated data. In the Chow test, the $\mathrm{H} 0$ hypothesis is that the width of the sources is the same (integrated data) as opposed to the $\mathrm{H}$ ) hypothesis that the width of the sources is the same (panel data method). If the error rate of the Chow test is less than $5 \%$, the panel data model is accepted, Otherwise, and the appropriateness of the research data, the combined or integrated data method is used to test the hypotheses. The results of the Chow test are presented in Table (4)

Table 4. Results of F-Limer or Chow test (width matching of cross-sectional origins)

\begin{tabular}{|c|c|c|c|c|}
\hline Type of method & Test result & $\begin{array}{c}\text { Error } \\
\text { level }\end{array}$ & $\begin{array}{c}\text { statistics } \\
\mathrm{F}\end{array}$ & Chav test \\
\hline Integrated data & $\begin{array}{c}\text { H0 is not } \\
\text { rejected }\end{array}$ & 0.24 & 1.093 & $\begin{array}{c}\text { H0: The same width of the } \\
\text { origin of the sections }\end{array}$ \\
\hline Integrated data & $\begin{array}{c}\text { H0 is not } \\
\text { rejected }\end{array}$ & 0.27 & 1.07 & $\begin{array}{c}\text { H0: The same width of the } \\
\text { origin of the sections }\end{array}$ \\
\hline
\end{tabular}


As can be seen, the $\mathrm{F}$ statistic is not significant at the $5 \%$ error level (Error level greater than 5\%). Thus, the Chow test strongly confirmed the similarity of the width of the origin in all periods. Hence, a combined method is accepted to estimate both models. Before estimating the model for testing research hypotheses, it is necessary to test the classical assumptions related to the regression model.

These assumptions are:

1- Equivalence of residual variance;

2- Normality of the rest of the model;

3- Lack of alignment of explanatory variables

4- Lack of self-correlation of error components.

\section{- Analysis of variance}

One of the regression assumptions is the absence of residual variance heterogeneity of the model. Considering the important effect of variance heterogeneity on estimation, standard deviation and statistical inference .It is necessary to realize the variance inequality before dealing with any estimate. Breusch-Pagan test, Glejser test and White test were used to match the remaining variance of the model. The test results showed the existence of variance homogeneity and in other words, the residues obtained from estimating the research model had a constant variance. Therefore, the ordinary least squares (OLS) method is used to estimate the research models.

Table 5. Results of variance homogeneity test of the remnants of the regression model

\begin{tabular}{|c|c|c|c|c|c|c|}
\hline & Model & $\begin{array}{c}\text { White } \\
\text { test }\end{array}$ & $\begin{array}{c}\text { Goljsar } \\
\text { test }\end{array}$ & $\begin{array}{l}\text { Breusch- } \\
\text { Pagan test }\end{array}$ & $\begin{array}{c}\text { Estimation } \\
\text { method }\end{array}$ & result \\
\hline $\begin{array}{c}\text { Statistics } \\
\text { F }\end{array}$ & Model 1 & 1.006 & 1.49 & 1.69 & OLS & $\begin{array}{c}\text { Homogeneity of } \\
\text { variance }\end{array}$ \\
\hline p.v & & 0.41 & 0.19 & 0.11 & & \\
\hline $\begin{array}{c}\text { Statistics } \\
\text { F }\end{array}$ & Model 2 & 1.2 & 1.61 & 1.23 & OLS & $\begin{array}{c}\text { Homogeneity of } \\
\text { variance }\end{array}$ \\
\hline p.v & & 0.3 & 0.15 & 0.28 & & \\
\hline
\end{tabular}

\section{- Normal residuals of the model}

The normality of the dependent variable must be tested before estimating the model. Abnormal distribution of this variable leads to a violation of the assumptions of this method for estimating parameters. Therefore, it is necessary to test the normality of the dependent variable of the research, In 
other words, the important assumption in the classical linear regression model is that the dependent variable and the error sentences are normally distributed. With this assumption in mind, estimators are also normally distributed.

Given the definite role of diagnostic tests in the analysis of results, it is very important to perform tests to confirm the assumption of normalcy. A common test in this regard is the Jark- bera-JB test.

In the Jark-bera test, we use the elongation and skewness of the waste sentence distribution to check whether the distribution of error sentences is normal or not.

In this test, the $\mathrm{H} 0$ hypothesis is that the error statements are normally distributed. And The opposite assumption also states that error statements are not normally distributed.

In this test, if the error level is less than 5\%, H1 hypothesis is confirmed and if the error level is greater than $5 \%$, assumption $\mathrm{HO}$ is accepted, and we conclude that the error sentences in the regression associated with each of the variables are normally distributed.

Table 6. Results of the normality test of the research dependent variable and Error Term

\begin{tabular}{|c|c|c|c|}
\hline Variable test & The rest of the model & bid-ask spread & Effective distribution \\
\hline $\begin{array}{c}\text { Statistics of } \\
\text { Jarque-Bera Test }\end{array}$ & 1.25 & 1.40 & 1.55 \\
\hline Error level & 0.69 & 0.55 & 0.38 \\
\hline
\end{tabular}

As can be seen, statistics on the normality of the dependent and residual variables of the model and their significance level, It indicates the confirmation of Hypothesis $\mathrm{H} 0$ and the rejection of Hypothesis $\mathrm{H} 1$. In other words, the dependent and residual variables of the research regression model do not have an abnormal distribution.

\section{Testing of hypotheses}

Before checking the model fits, we need to employ the F-Limer test to examine the use of panel data with fixed effects against the panel data method for the above model. Table $\varepsilon$ shows the results of the F-Limer test for the research model.

Regarding the statistic and an alpha level of the F-Limer test and the confirmation of the null hypothesis for the research models, the panel-data model is accepted. 


\section{Iranian Journal of Finance, 2021, Vol. 5, No. 1 (Babajani, J.)}

Hypothesis 1: Pricing of information asymmetry

The present study uses Durbin-Watson's test to determine the self-correlation of the model. If the value of the Durbin-Watson statistic approximates 2, the independence of the error term of the model can be accepted. Besides, Fisher's test is used for the examination of the total significance of the model. Table 7 depicts the results achieved from the estimation of research models.

Table 7. Estimation results of research models

\begin{tabular}{|c|c|c|c|c|c|c|c|c|}
\hline & \multicolumn{4}{|c|}{ Bid and ask Spread } & \multicolumn{4}{|c|}{ Effective Spread } \\
\hline Variable & Coefficient & $\begin{array}{c}\mathrm{T} \\
\text { static }\end{array}$ & $\begin{array}{l}\text { Sig. } \\
\text { level }\end{array}$ & VIF & Coefficient & $\begin{array}{c}\mathrm{T} \\
\text { static }\end{array}$ & $\begin{array}{l}\text { Sig. } \\
\text { level }\end{array}$ & VIF \\
\hline $\begin{array}{l}\text { Information Asymmetry } \\
\text { (IA) }\end{array}$ & 0.416 & 2.222 & 0.027 & 1.06 & 0.523 & 0.715 & 0.475 & 1.09 \\
\hline Corporate Governance (CG) & -0.594 & $\begin{array}{c}- \\
2.599\end{array}$ & 0.010 & 1.12 & -0.035 & $\begin{array}{c}- \\
0.169\end{array}$ & 0.866 & 1.06 \\
\hline $\mathrm{IA} \times \mathrm{CG}$ & -2.696 & $\begin{array}{c}- \\
1.681\end{array}$ & 0.093 & 1.23 & -0.197 & $\begin{array}{c}- \\
2.167\end{array}$ & 0.030 & 1.12 \\
\hline Financial Leverage & -0.099 & $\begin{array}{c}- \\
2.104\end{array}$ & 0.036 & 1.08 & -0.106 & $\begin{array}{c}- \\
2.825\end{array}$ & 0.005 & 1.10 \\
\hline Return of Assets & -0.006 & $\begin{array}{c}- \\
0.171\end{array}$ & 0.865 & 1.66 & 0.036 & 0.915 & 0.361 & 1.64 \\
\hline Company Size & 0.009 & 0.501 & 0.617 & 1.07 & 0.003 & 0.231 & 0.817 & 1.05 \\
\hline Fixed Component & 0.035 & 0.320 & 0.749 & - & 0.132 & 1.449 & 0.148 & - \\
\hline Determination Coefficient & 0.18 & & & & 0.162 & & & \\
\hline $\begin{array}{c}\text { Adjusted Determination } \\
\text { Coefficient }\end{array}$ & 0.13 & & & & 0.113 & & & \\
\hline Waldrich Statistic & $(0.223)$ & 480 & & & $(0.236) 1$ & 547 & & \\
\hline Heteroscedasticity Test & $(0.208)$ & & & & $(0.254) 1$ & & & \\
\hline Durbin-Watson Statistic & 1.82 & & & & 1.870 & & & \\
\hline F Statistic & 2.79 & & & & 3.307 & & & \\
\hline F-statistic Probability & 0.00 & & & & 0.003 & & & \\
\hline
\end{tabular}

The results of the first and second models of the research are described in Table (8). As can be seen, In the first model (Bid and ask Spread) Fisher statistics (2.69790 and the second model (3.30) were significant at the level of 
$5 \%$ and indicates the overall significance of both models is an estimate. Therefore, both research models are significant in general and independent and control variables have the ability to explain the dependent variable. Besides, the adjusted coefficient of determination in the first model (R2) is 0.138 , this number indicates that approximately 0.14 of the dependent variable variables of the first model can be attributed to the independent and control variables, and another 0.86 are due to other factors that are beyond the reach of the researcher. The larger the value of this index, the greater the scatter of points around the regression line. This value is also 0.11 in the second model.

Durbin-Watson statistics in the first and second models were (1.82) and (1.87), respectively, and indicates the absence of the first-order serial autocorrelation problem in the perturbation components of both models is estimated.

Therefore, the results of the estimated model are not false and the model estimate is reliable (normal should be between 1.5 and 2.5), It also shows the value of the variance inflation index (VIF), the independent variables of the first model do not have a strong correlation problem with each other. When the value of the VIF statistic is less than 5 (in some other sources the number 10 is also mentioned), there is no evidence of multiple alignments between model independent variables. These interpretations also apply to the second model.

As the table above illustrates, statistic $t$ is related to the null hypothesis respecting the no effect of information asymmetry on capital cost equals 2.222 and 0.715 in models 1 and 2 . Hence, the null hypothesis is rejected at the alpha level of 5\%. As a result, information asymmetry, in the model that is based on the bid and ask spread criterion, directly and significantly impact the capital cost.

Statistic $\mathrm{t}$ related to the null hypothesis on the no effect of corporate governance on capital cost equals 2.599 and -0.169 , respectively, in models 1 and 2; thus, this hypothesis is rejected at the alpha level of $5 \%$. Consequently, corporate governance, in the model based on the bid and ask spread criterion, negatively and reversely impacts capital cost.

Furthermore, according to the test of the role of corporate governance in moderating the relationship between information asymmetry and capital cost, the $t$ statistic considered in models 1 and 2 equals -1.681 and -2.167 , indicating the confirmation of the mentioned hypothesis.

The results of this test show that since the coefficient in the bid and ask spread and effective spread is significant, corporate governance influences the 


\section{Iranian Journal of Finance, 2021, Vol. 5, No. 1 (Babajani, J.)}

pricing of information asymmetry.

Hypothesis 2: Testing the role of corporate governance point in capital cost change

The test of the second hypothesis is, in fact, testing capital cost and the characteristics of the information environment. For the test of this hypothesis, the companies are categorized into five quantiles according to the index of corporate governance. Then, the companies are categorized into 5 quantiles based on the index of information asymmetry degree. The results derived from every one of these quantiles are described below:

Table 8. Envelope portfolio of information asymmetry

\begin{tabular}{|c|c|c|c|}
\hline \multicolumn{3}{|c|}{ Envelope Portfolio of Information Asymmetry by Corporate Governance } \\
\hline \multirow{4}{*}{} & & \multicolumn{2}{|c|}{ Information Asymmetry Criteria } \\
\cline { 2 - 4 } & & $\begin{array}{c}\text { Bid and Ask Spread } \\
\left(\mathrm{Q}_{1}-\mathrm{Q}_{5}\right)\end{array}$ & Effective Spread $\left(\mathrm{Q}_{1}-\mathrm{Q}_{5}\right)$ \\
\hline \multirow{5}{*}{ Corporate } & First & -0.0114 & -0.0625 \\
& Quintile & 3.1241 & -2.1763 \\
\cline { 2 - 4 } Governance Quintile & Second & 0.0218 & -0.0541 \\
& Quintile & 3.3320 & -3.3912 \\
\cline { 2 - 4 } & Third & 0.0871 & 0.0168 \\
& Quintile & 3.1901 & 3.7490 \\
\cline { 2 - 4 } & Fourth & 0.1423 & 0.0519 \\
& Quintile & 2.4516 & 2.0981 \\
\cline { 2 - 4 } & Fifth & 0.1884 & 0.0974 \\
& Quintile & 3.1292 & 3.4567 \\
\hline
\end{tabular}

Concerning the table above, we can assert that the information asymmetry coefficient increases as the corporate governance decreases, such that the relevant coefficient is minimum in the first quintile (higher corporate governance). The results obtained from the capital cost change related to this hypothesis are represented in the below table:

Table 9. Capital cost change

\begin{tabular}{|c|c|c|c|c|c|c|c|c|}
\hline & & \multicolumn{7}{|c|}{ Information asymmetry } \\
\hline & \multirow[b]{2}{*}{$\begin{array}{l}\text { Quint } \\
\text { ile }\end{array}$} & \multirow[b]{2}{*}{ Variable } & \multicolumn{2}{|c|}{$\mathrm{Q}_{1}$} & \multicolumn{2}{|c|}{$\mathrm{Q}_{5}$} & \multicolumn{2}{|c|}{ Envelope } \\
\hline & & & $\begin{array}{c}\text { Coeffici } \\
\text { ent }\end{array}$ & $\begin{array}{c}\mathrm{t} \\
\text { statisti } \\
\mathrm{c}\end{array}$ & $\begin{array}{c}\text { Coeffici } \\
\text { ent }\end{array}$ & $\begin{array}{c}\mathrm{t} \\
\text { statistic }\end{array}$ & $\begin{array}{c}\text { Coeffici } \\
\text { ent }\end{array}$ & $\begin{array}{c}\mathrm{t} \\
\text { statistic }\end{array}$ \\
\hline $\begin{array}{l}\text { Corpor } \\
\text { ate } \\
\text { governa }\end{array}$ & $\mathrm{Q}_{1}$ & $\begin{array}{c}\text { Fixed } \\
\text { componen } \\
\mathrm{t} \\
\end{array}$ & 0.09025 & 1.6961 & 0.1761 & $\begin{array}{c}* * * 1.8 \\
516\end{array}$ & 0.8026 & $\begin{array}{c}* * 2.50 \\
42\end{array}$ \\
\hline nce & & $\mathrm{mkt}$ & 0.1541 & *3.091 & 0.3652 & $* * 2.25$ & 0.1649 & $* * 2.44$ \\
\hline
\end{tabular}




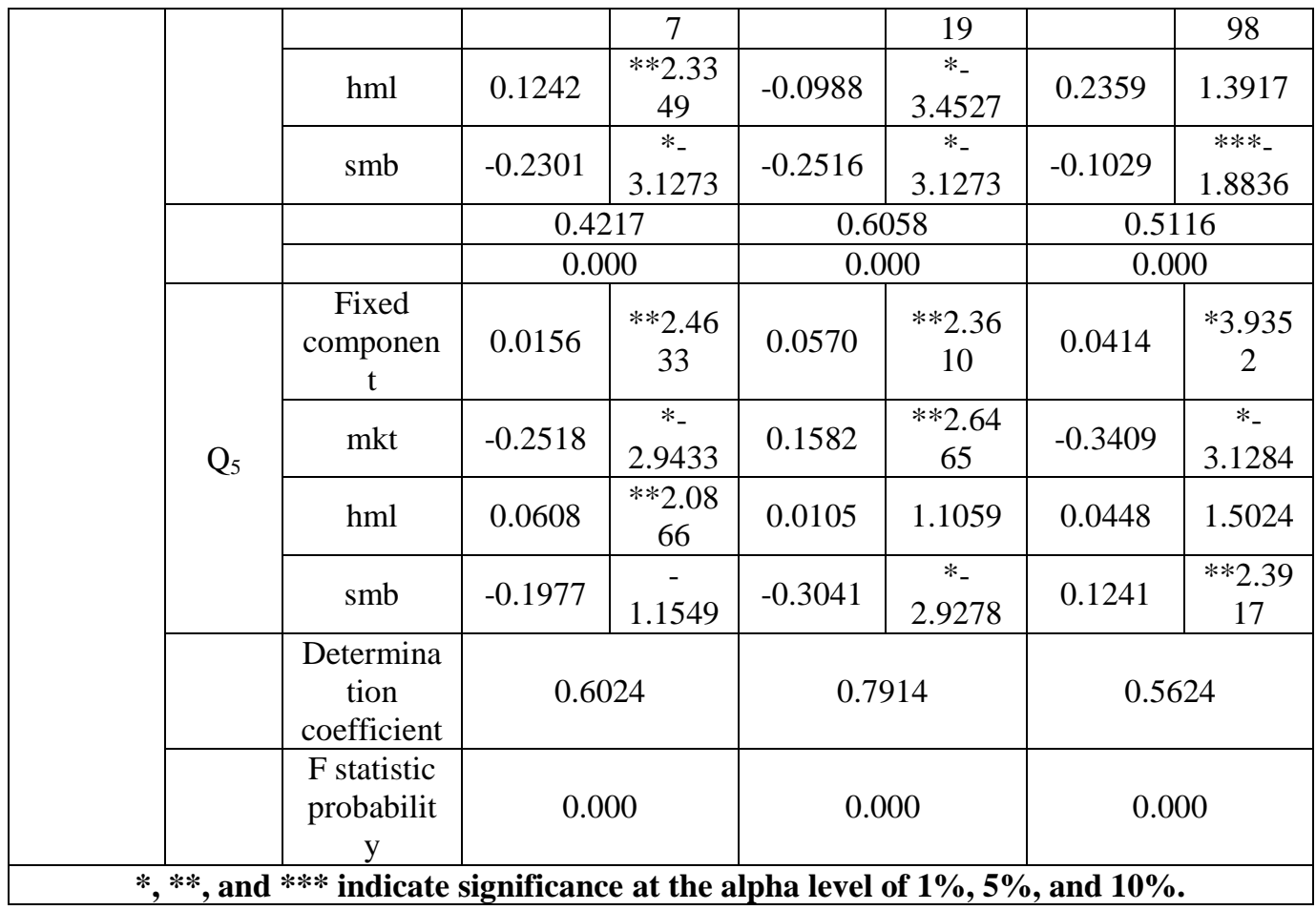

The variable considered in the second hypothesis is the fixed component of $\mathrm{aH}$. If aH is significantly larger than 0 , the companies with high information asymmetry will acquire high-risk adjusted capital cost compared to the companies with low information asymmetry. Given the above table and according to the first and last categories and their comparison, we can claim that the second hypothesis of the research is confirmed. In other words, there is a significant relationship between the upper and lower categories of information asymmetry concerning the capital cost dimension. We can also assert that capital cost shifts in light of the changes in information asymmetry.

\section{Conclusion}

This study investigated the pricing of information distribution based on the corporate governance point. The results of the first hypothesis regarding the effect of corporate governance on capital costs were confirmed. To identify optimal investment opportunities, investors need clear and uniform information. Francis et al. (2004) argue that corporate governance facilitates the analysis and identification of financial information, precludes improper selection, and impedes the imposition of excess costs. The results of this hypothesis correspond to the investigations of Lambert et al. (2012). In this 
respect, we can posit that information asymmetry increases the capital cost of the company. When information asymmetry increments, the innate value of the company's stock differs from the value with which investors want to trade that stock. The present difference in the information composition between private and public information makes less informed traders discern that they are in an improper informational status and thus maintain fewer assets. This, in turn, leads the price of stocks with a high degree of private information downwards, and; thus, the information asymmetry of these companies upsurges.

With respect to their evaluations on the characteristics of the information environment, investors reconsider the rate of informational risk. More desirable and favorite information environments reduce the risk of information. As the risk declines, they demand less return, and, as a result, the capital cost of the company decreases. When investors enjoy varying information about securities or market mechanisms in the capital market, they differ in their recognition of a single situation; in other words, there will be information asymmetry. Thinking that there is evidently information asymmetry, less-informed investors may disregard stock trading or leave the stock market totally. One of the main factors in the improvement of economic efficiency is the governance system of the institution (corporate governance), which encompasses a set of relationships among the company management, board of directors, stockholders, and other beneficiaries. The governance system of the institution renders a structure by which its goals are adjusted and the tools for the attainment of these goals and performance supervision are identified. This system creates in management the necessary motivation for the realization of the institution's goals and paves the way for effective supervision. Thus, companies exploit resources that have more effectiveness.

Respecting the second hypothesis of the research, corporate governance leads to a difference between companies with high information asymmetry and those with low information asymmetry in their capital cost. By providing qualified information, corporate governance reduces the general ambiguity and thus minimizes the profit that certain investors earn by gaining the private information of the company. In the state of high corporate governance, the effect of liquidity decline, which stems from the disinclination of some certain investors to the collection of private information and participation in the stock trade of a company, is insignificant and negligible. However, in a poor state of corporate governance, this effect can be significant and measurable, especially for the conditions that require the unique risk of the company and not the market-level factors. The results of these assumptions are in line with the investigations of Verchia (2001). 
Having a capital market with low trade costs is of utmost importance in the emerging and developed markets. The capital market with low trade costs leads to the optimal allocation of capital and is an advantage for liquidity suppliers. Nonetheless, the recognition of trade costs in some capital markets such as Iran is important in two aspects: first, due to its effect on investment strategies and, second, due to the strategy of asset allocation. By planning and controlling using a strong corporate governance system, we can alleviate the effects of trade costs and witness an increase in the prosperity of the stock exchanges in the capital market of Iran. Corporate governance refers to the clarity, trust, and confidence in the relationships of the stockholders, board of directors, management, and employees and determines the power rate and responsibility of each in offering sustainable value to all stockholders. To attract human and financial capitals to the company and ensure the sustainability of value creation, companies determine their policies in such a way that they attract the trust of all stockholders. Proper corporate governance guarantees the appropriate trust relationships between the company and its beneficiaries. The better the corporate governance of companies is, the less financing cost will be imposed, and the less return will be demanded by investors. The more the costs of the agency minimize, the more the investors trust in, and, as a result, the more financial capital is supplied to the companies.

\section{Applied suggestions}

1. The company managers are suggested to broaden their knowledge on corporate governance to be able to play their parts properly in companies, attract many investors in this way, and also increase the value of the company and stockholders by decreasing the agency costs and information asymmetry.

2. The Government and Organization of the Stock Exchange are suggested to make the necessary efforts to create a competitive atmosphere among diverse industries and companies so that they can build a suitable equilibrium between the rights of stockholders, on the one hand, and the needs and authorities of the board of directors, on the other hand. In this way, they create reasonable confidence for the suppliers of financial resources and rights of stockholders and increase the efficacy of the companies' management in the conditions of information asymmetry.

3. The Organization of Stock Exchange is recommended to design and compile the quality and efficacy ranking system of corporate governance by reviewing the corporate governance instructions of security exchanges that are based on the internal indices of corporate governance in the present 
study and rank all companies that are accepted in Stock Exchange based on this system and then inform the public. It is because it seems that, in the political and economic conditions that govern Iran, few beneficiaries and investors are aware of the system of the corporate governance quality and the effect of this system on the values and effective management of companies. Therefore, the Stock Exchange Organization can provide investors and beneficiaries with a brighter horizon for investment in this company types by ranking the companies and truly and timely releasing this information. Moreover, due to the unstable positions of managers in Iran, the implementation of this policy sufficiently motivates them to work more effectively and efficiently to preserve their positions and statuses and prevent exclusion from the competitive market. This practice reduces the costs of the agency since corporate governance solely approves the designs and plans in many of the Iranian companies and is accompanied by numerous deficiencies. Hence, the managers of these companies properly know that the implementation of the corporate governance quality ranking by the Stock Exchange will easily exclude them from the capital market and pave the way for their disorganization in case they possess corporate governance weaker than other competitors. Thus, they always try to increase the value of stockholders. It is hoped that the implementation of the corporate governance ranking policy by the Stock Exchange Organization leads the economy market of Iran to efficient markets and, accordingly, decreases information asymmetry.

Funding: This research received no external funding.

\section{References}

Akins, B., Ng, J and Verdi, R. (2012); "Investor competition over information and the pricing of information asymmetry", The Accounting Review, Vol. 87 No. 1, pp.35-58.

Atias C., J. Core, D. (1987). When does information asymmetry affect the cost of capital? Journal of Accounting Research 49 (1): 1-40.

Berowan, C., and M. Hili'ist, (2007), A re-examination of disclosure level and the expected cost of equity capital, Journal of Accounting Research, 40(1), 21-40.

Ben, T. W., Kahle, K. M., \& Stulz, R. M. (2020). Why do U.S. firms hold so much more cash than they used to? Journal of Finance, 64(5), 1985-2021. 
Chang, E., Lin, T., Ma, X., (2014). Governance through trading and corporate investment decisions. Working paper, University of Hong Kong.

Chen, C., Xiumin M., Roychowdhury, S., Xin W., and Matthew, B. (2016). Clarity Begins at Home: Internal Information Asymmetry and External Communication Quality. Forthcoming the Accounting Review.

Chen, J.-H., Choi, and Liang, D. (2017). Financial Statement Comparability and the Ability of Current Stock Returns to Reflect the Information in Future Earnings, available at http://ssrn.com/abstract $=2337571$.

Derabitez, G., Kothari, S., Verdi, R. (2016). The benefits of financial statement comparability. Journal of Accounting Research, 49 (4), 895-931.

Diata, D., and R. Verrecchia. (2018). Disclosure, liquidity and the cost of capital. Journal of Finance 46 (4): 1325-1359.

Derato, P. J \& Kim, J. (2010). Who's informed? An analysis of stock ownership and informed trading. An Analysis of Stock Ownership and Informed Trading (June 4), AFA

Dou, Y., Hope, O., Thomas, W., Zou, Y., (2015). Blockholder exit threats and financial reporting quality. Working paper, University of Toronto.

Easley, D., and M. O'Hara. 2004. Information and the cost of capital. Journal of Finance 59 (4):1553-1583.

Fishman, M., and Hagerty, K. (1987) Insider trading and the efficiency of stock prices, RAND Journal of Economics 23, 106-122.

Ferancis, R., Kraft, A. and Zhang, H. (2005). Financial reporting frequency, information asymmetry, and the cost of equity, Journal of Accounting and Economics, 54(2-3), 132-149.

Golep, A., G. and L. Zarowin, (2002), SEC Regulation Fair Disclosure, Information, and the Cost of Capital, Working Paper: Washington University; University of Pennsylvania; Case Western Reserve University.

Guopta, H., \& Sharma, B. (2018). A Better Measure of Institutional Informed Trading. Contemporary Accounting Research, 33(2), 815-850.Joenz, M. C. (2005). Agency Costs of Free Cash Flow, Corporate Finance, and Takeovers. The American Economic Review, 76(2), 323-329.

Johnston, J. A and Sow, C. (2019). Accruals quality and price synchronicity. University of Louisiana state \& SSRN.

Kyle, A. (1985). Continuous auctions and insider trade. Econometrica 53, 13151335.

Kamono, S. \& Wefimis, S. A. (2005). "How Disclosure Quality Affects the Level of Information Asymmetry". Review of Accounting Studies. 12: 443-477. 
Kaiy L., Stulz, R., \& Williamson, R. (2019). Does the contribution of corporate cash holdings and dividends to firm value depend on governance? A cross-country analysis. Journal of Finance, 61(6), 2725-2751.

Kormiter .M. Venkatesh, P., \& Chiang, R. (2010). Information Asymmetry and the Dealer TM s Bid-Ask Spread: A Case Study of Earnings and Dividend Announcements. Journal of Finance, 41(5), 1089-1102.

Lambert, R., C. Leuz, and R. Verrecchia. (2012). Information asymmetry, information precision, and the cost of capital. Review of Finance (forthcoming).

Landehem, M. and Mirez .V.(2002). The relationship among information asymmetry, dividend policy and ownership structure. Finance Research Letters 20.

Luriy, R. and L. Myers (2005). "Bringing the future forward: The effect of disclosure on the returns earnings relation". Journal of Accounting Research 40(3): pp 809.

Merton, R., (1987), A Simple Model of Capital Market Equilibrium with Incomplete Information, Journal of Finance 43, 483-510.

Minik and, D., Toga, M. (2010). Option volume and stock prices: Evidence on where informed traders trade. The Journal of Finance, 53 (2), 431-465.

Nagar, Z., Musa, H. \& Debnarova, L (2018). The impact of governance on information asymmetry in Slovakia. Dol:10.18844/gjhss.V3i4.1511.

Owen .A. L. Benjamin, and J.S. Jen. (2010). Corporate governance and stock liquidity dimensions: Panel evidence from the pure order-driven Australian market. International Review of Economics and Finance 50: 275-304

Ebrahimi, E., Mehrani, K., Nazari, M. (2020). Competitiveness and Pricing of Accounting Information Asymmetry and Quality. Empirical Research in Accounting, 9(3), 179-202. doi: 10.22051/jera.2019.21292.2110

Vakilian Aghouie, M., Abbaszadeh, M., Salehi, M. (2016). Investigating the Relationship between Audit Return and Audit Quality in the Pharmacological Companies Listed on the Tehran Stock Exchange. Journal of Health Accounting, 5(1), $107-133$

Rashidi baghi M, Khodadadi V, Ramzan Ahmadi M, Farazmand H. (2019) Modeling the Interactive Effect of Disclosure Quality on Information Asymmetry Pricing. Quarterly financial accounting journal; 11(41):103-125

Rahimian, N., Salehnejad, S., Saleki, A. (2010). Relationship between the Some of Corporate Governance Mechanisms and Information Asymmetry in the Firms listed in Tehran Stock Exchange. Accounting and Auditing Review, 16(4).

Emamgholipour, M., Yadollahzadeh Tabari, N. (2014). The Effect of Corporate Governance and Audit Quality on the Weighted Average Cost of Capital: 
Comparative Analysis Based on Auditor Size, Firm Size and Income Smoother and non-Smoother Companies. Asset Management and Financing, 2(3), 29-48.

Baghani, A., Ahmadi, N., Setak, H. (2018). The Relationship between Corporate Governance and Information Asymmetry with Stock Returns in Companies Listed in Tehran Stock Exchange, 9(18), 57-71.

Joudi, S., Mansourfar, G., Didar, H. (2019). Internal and External Corporate Governance Quality, Information Asymmetry and Cash Holdings: Increase or Decrease in the Firm Value? Accounting and Auditing Review, 26(1), 39-64

Joudi, S., Mansourfar (PhD), G. (2019). Information Asymmetry, Internal and External Dimensions of Corporate Governance Quality: Improving or Worsening Audit Quality, 10(3), 199-231. doi: 10.22103/jak.2019.12497.2751

Sharder, E. (2020). Corporate Governance and Product Market Competition. Working Paper, Madras School of Economics, India.

Solomon, B. C. (2010). The effect of accounting comparability on the accrualbased and real earnings management. Journal of Accounting and Public Policy, 35(5), 513-539.

Scott E. Seavey, and David B. Smith (2009) Comparability and Cost of Equity Capital. Accounting Horizons: June 2017, Vol. 31, No. 2, pp. 125-138.

Wang, J.and Ki,m, (2007). A model of intertemporal asset prices under asymmetric information. The Review of Economic Studies, 60 (2), 249-28

Bibliographic information of this paper for citing:

Babajani, Jaafar \& Akbari, Mohsen (2021). Modeling the effect of environmental corporate governance rating in the pricing information asymmetry. Iranian Journal of Finance, 5(1), 91-121.

Copyright @ 2021, Jaafar Babajani and Mohsen Akbari 